\title{
Correction to: Physiological response of Kobresia pygmaea to temperature changes on the Qinghai-Tibet Plateau
}

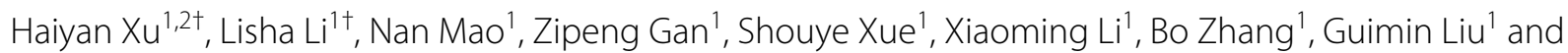
Xiaodong $\mathrm{Wu}^{2^{*}}$

Correction to: BMC Plant Biol 22, 51 (2022)

https://doi.org/10.1186/s12870-022-03428-9

Following publication of the original article [1], it was noted that due to a typesetting error, authors, Haiyan $\mathrm{Xu}$ and Lisha Li were not tagged as equal contributors.

${ }^{\dagger}$ Haiyan $\mathrm{Xu}$ and Lisha Li contributed equally.

The original article [1] has been corrected.

\section{Author details}

${ }^{1}$ School of Environmental and Municipal Engineering, Lanzhou Jiaotong University, Lanzhou, China. ${ }^{2}$ Cryosphere Research Station on the Qinghai-Tibet Plateau, State Key Laboratory of Cryospheric Science, Northwest Institute of Eco-Environment and Resources, Chinese Academy of Sciences, Lanzhou, China.

Published online: 10 February 2022

\section{Reference \\ 1. $\mathrm{Xu} \mathrm{H}, \mathrm{Li}$ L, Mao N, et al. Physiological response of Kobresia pygmaea to temperature changes on the Qinghai-Tibet plateau. BMC Plant Biol. 2022;22:51. https://doi.org/10.1186/s12870-022-03428-9.}

The original article can be found online at https://doi.org/10.1186/s12870022-03428-9.

\footnotetext{
*Correspondence: wuxd@|zb.ac.cn

${ }^{\dagger}$ Haiyan Xu and Lisha Li contributed equally to this work.

${ }^{2}$ Cryosphere Research Station on the Qinghai-Tibet Plateau, State

Key Laboratory of Cryospheric Science, Northwest Institute of Eco-

Environment and Resources, Chinese Academy of Sciences, Lanzhou,

China

Full list of author information is available at the end of the article
}

(C) The Author(s) 2022. Open Access This article is licensed under a Creative Commons Attribution 4.0 International License, which permits use, sharing, adaptation, distribution and reproduction in any medium or format, as long as you give appropriate credit to the original author(s) and the source, provide a link to the Creative Commons licence, and indicate if changes were made. The images or other third party material in this article are included in the article's Creative Commons licence, unless indicated otherwise in a credit line to the material. If material is not included in the article's Creative Commons licence and your intended use is not permitted by statutory regulation or exceeds the permitted use, you will need to obtain permission directly from the copyright holder. To view a copy of this licence, visit http://creativecommons.org/licenses/by/4.0/. The Creative Commons Public Domain Dedication waiver (http://creativeco mmons.org/publicdomain/zero/1.0/) applies to the data made available in this article, unless otherwise stated in a credit line to the data. 